\title{
Adölesan Bir Annede Mortal Seyreden H1N1 Pnömoni Vakası
}

\author{
A Mortal H1N1 Pneumonia Case in an Adolescent Mother \\ Bahri Elmas $^{1}$, Onur Bircan ${ }^{1}$, Mehmet Fatih Orhan ${ }^{2}$, Öner Özdemir ${ }^{3}$ \\ ${ }^{1}$ Sakarya Üniversitesi Tip Fakültesi Pediatri ABD, Sakarya \\ ${ }^{2}$ Sakarya Üniversitesi Tip Fakültesi Pediatri ABD, Pediatrik Hematoloji-Onkoloji BD, Sakarya \\ ${ }^{3}$ Sakarya Üniversitesi Tip Fakültesi Pediatri ABD, Pediatrik Allerji-İmmünoloji BD, Sakarya
}

\author{
Yazışma Adresi / Correspondence: \\ Dr. Onur Bircan \\ Sakarya Üniversitesi Eğitim ve Araştırma Hastanesi Pediatri Kliniği, Adapazarı/Sakarya \\ T: +90505 $2465112 \quad$ E-mail: dronurbircan@gmail.com \\ Orcid \\ Bahri Elmas http://orcid.org/0000-0001-9034-6109 \\ Onur Bircan https://orcid.org/0000-0002-0920-7652 \\ Mehmet Fatih Orhan https://orcid.org/0000-0001-8081-6760 \\ Öner Özdemir https://orcid.org/0000-0002-5338-9561
}

Geliş Tarihi / Received : 26-11-2019 Kabul Tarihi / Accepted : 08-12-2019 Yayın Tarihi / Online Published: 27-12-2019

Elmas B., Bircan O., Orhan M.F., Özdemir Ö., Adölesan Bir Annede Mortal Seyreden H1N1 Pnömoni Vakası, J Biotechnol and Strategic Health Res. 2019;3(3):255-259 DOI: 10.34084/bshr.650966

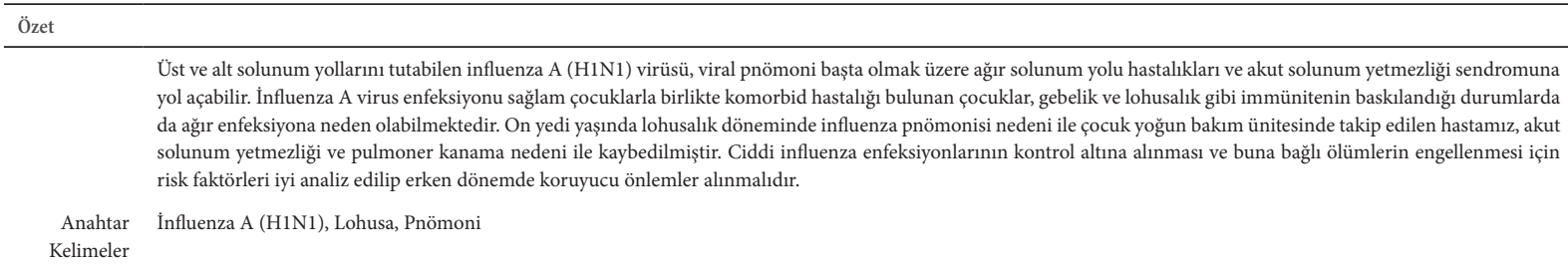
yol açabilir. İnfluenza A virus enfeksiyonu sağlam çocuklarla birlikte komorbid hastalığı bulunan çocuklar, gebelik ve lohusalık gibi immünitenin baskılandığı durumlarda da ağır enfeksiyona neden olabilmektedir. On yedi yaşında lohusalık döneminde influenza pnömonisi nedeni ile çocuk yoğun bakım ünitesinde takip edilen hastamız, akut solunum yetmezliği ve pulmoner kanama nedeni ile kaybedilmiştir. Ciddi influenza enfeksiyonlarının kontrol altına alınması ve buna bağlı ölümlerin engellenmesi için risk faktörleri iyi analiz edilip erken dönemde koruyucu önlemler alınmalıdır.

Anahtar İnfluenza A (H1N1), Lohusa, Pnömoni

Kelimeler

Abstract

The influenza A (H1N1) virus, which may involve the upper and lower respiratory tracts, can lead to severe respiratory diseases, especially viral pneumonia, and acute respiratory failure syndrome. Influenza A virus infection can cause severe infection in healthy children, as well as children with comorbid disease and immunosuppressed conditions such as pregnancy and puerperium. A seventeen years old patient who was followed up in pediatric intensive care unit due to influenza pneumonia during postpartum period died due to acute respiratory failure and pulmonary hemorrhage. In order to control severe influenza infections and prevent deaths, risk factors should be analyzed well and preventive measures should be taken in the early period.

Keywords Influenza A (H1N1), Pneumonia, Puerperium 


\section{GIIRIŞ}

İnfluenza A virus (İAV) H1N1 enfeksiyonu mevsimsel gripteki ateş, öksürük, burun akıntısı, halsizlik, yaygın eklem ve kas ağrısı, boğaz ağrısı, baş ağrısı gibi klasik semptomların yanında bulantı, kusma, ishal ve karın ağrısı gibi gastrointestinal semptomlarla da seyredebilen bir solunum yolu enfeksiyonudur ${ }^{1}$. Üst ve alt solunum yollarını tutabilen $\mathrm{H} 1 \mathrm{~N} 1$ virüsü viral pnömoni başta olmak üzere ağır solunum yolu hastalıklarına yol açarak akut solunum yetmezliği sendromu (ARDS) ile sonuçlanabilir² . Ağır İAV enfeksiyonuna bağlı en sık ölüm nedeni ARDS'dir³. İAV gebe, lohusa veya komorbid hastalığı bulunan çocuk ve erişkinlerin yanında genç erişkin, çocuk ve risk faktörü olmayan kişilerde de ağır enfeksiyona neden olabilmektedir ${ }^{4}$. Düşük sosyoekonomik düzeye sahip, adölesan dönemde gebe kalan ve lohusalık döneminde İAV pnömonisine bağlı komplikasyonlar nedeni ile kaybedilen bir vaka, hastalığın morbidite ve mortalitesine dikkat çekmek amacıyla sunulmuştur.

\section{Olgu}

Üç ay önce normal vajinal yol ile doğum yapan ve sağlıklı bir kız bebeğe sahip, öncesinde her hangi bir hastalığı olmayan 17 yaşındaki hasta 1 hafta önce başlayan hafif üst solunum yolu semptomlarına bulantı, kusma, ishal, karın ağrısı şikayetlerinin eklenmesi ve ateş yüksekliğinin olması üzerine acil servise başvurdu. Fizik muayenede genel durumu kötü, bilinci bulanık, akciğerlerde bilateral krepitan ralleri mevcuttu. Vücut sicaklığ $38,7^{\circ} \mathrm{C}$, kalp tepe atımı 110/dk, sPO2 \%92, tansiyon arteriyel 90/40 mm/Hg, solunum sayıs 36/dk, kapiller dolum zamanı $>2$ sn idi. Laboratuvar incelemesinde hemoglobin 11,3 g/dL, lökosit sayısı 9,82 k/uL, nötrofil sayısı 1,32 k/uL, platelet sayısı 61700 /uL, C-reaktif protein (CRP) $354 \mathrm{mg} / \mathrm{L}$, prokalsito$\operatorname{nin}$ (Pct) 146,73 ng/dL, üre 137,32 mg/dL, kreatinin $2 \mathrm{mg} /$ $\mathrm{dL}, \mathrm{pH} 7,25, \mathrm{pCO} 243,9 \mathrm{~mm} / \mathrm{Hg}, \mathrm{HCO} 318,1 \mathrm{mmol} / \mathrm{L}$ ve gaitada adenovirüs serolojisi menfi bulundu. Akciğer grafisinde bilateral pnömonik infiltrasyonlar gözlendi (Resim 1). Yoğun bakım ihtiyacı gösteren komplike pnömoni nedeniyle ampirik antibiyotik tedavisi ve oseltamivir başlan- dı. Hasta ilerleyen solunum sıkıntısı ve bilincinin bulanık olması nedeniyle entübe edilerek mekanik ventilatöre alınd1. Yatışının 2. gününde ARDS tablosu gelişen hasta uygun ventilatör modlarında ve aralıklı prone pozisyonunda takip edildi. Nazofarengeal sürüntü örneğinde PCR ile H1N1 pozitif saptand. Kan, idrar, boğaz ve trakeal aspirat kültürlerinde üreme olmadı. Yatışının 20. gününde mekanik ventilatörden ayrılan hasta, yüksek akışlı nazal kanül oksijen tedavisine alındı. Sol akciğerde solunum seslerinin düzelmemesi ve direkt grafide konsolidasyon alanlarının devam etmesi üzerine yapılan toraks bilgisayarlı tomografi (BT) incelemesinde sol akciğer lingular segment ve alt lob posterobazal segmentte bronşiektazik alanlar izlendi ve nekrotizan pnömoni lehine değerlendirildi (Resim 2). Yatışının 30. gününde masif pulmoner kanama gelişen hasta ex oldu.
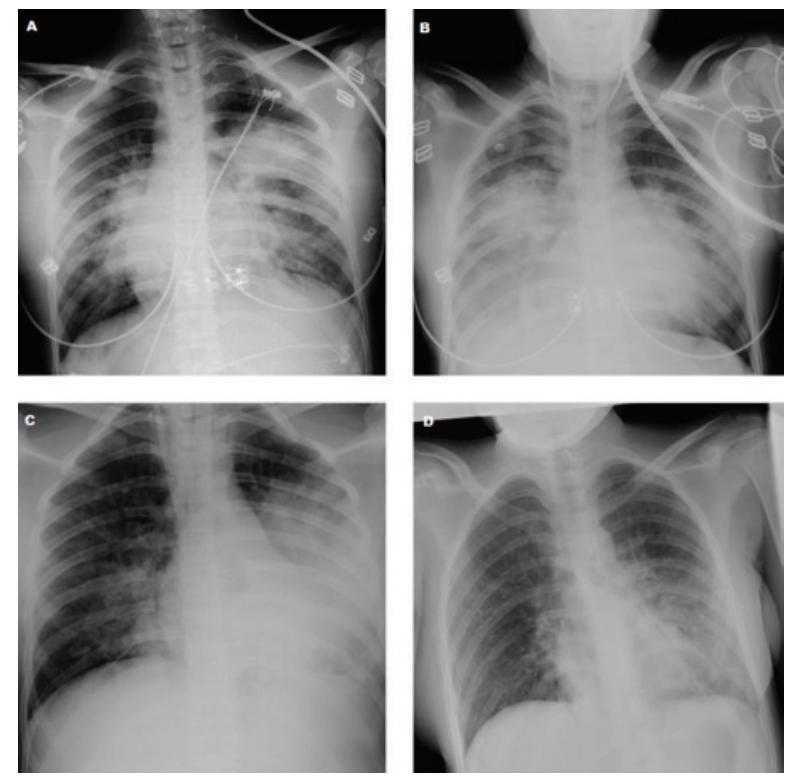

Resim 1: Hastanin 1. (Grafi A), 4. (Grafi B), 17. (Grafi C) ve 30. gündeki (Grafi D) direkt grafi görüntüleri. 


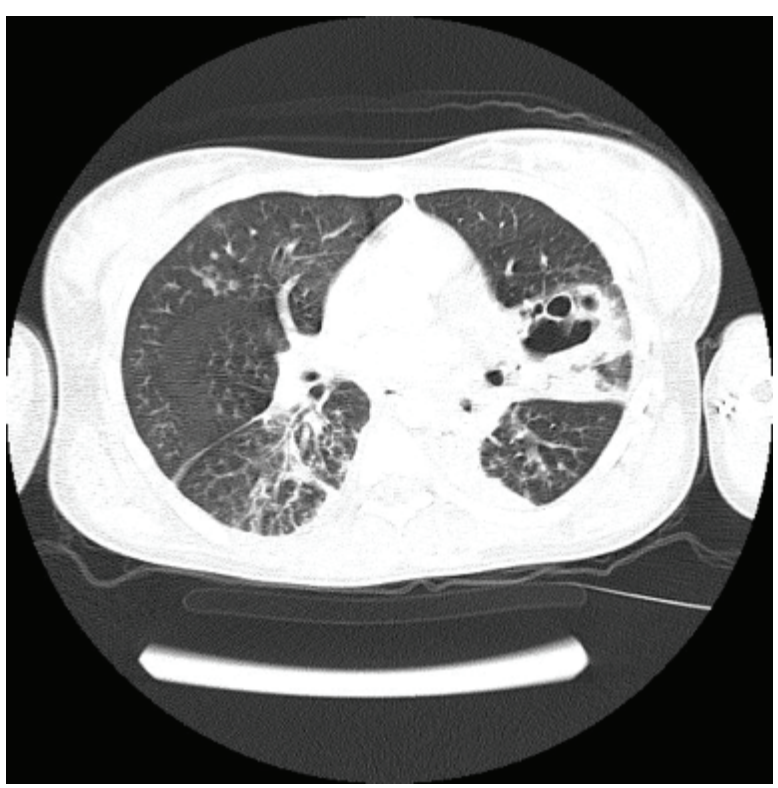

Resim 2: Sol akciğerde kistik ve tübüler bronşiektazi alanla$r$, her iki akciğerde hava bronkogramları içeren konsolidasyon alanlart izlenmektedir.

\section{Tartışma}

İnfluenza A virus enfeksiyonlarında ani başlayan yüksek ateş, burun akıntısı, baş ağrısı, kuru öksürük, farenjit, konjonktivit, bulantı, kusma, ishal ve miyalji sıklıkla gözlenir. Semptomlar genellikle etkene maruziyetten 1 - 2 gün sonra başlayıp 7-14 gün içerisinde sonlanır. Ateş semptomların başlangıcından itibaren 12 saat içerisinde hızla yükselir. Hastalık başlangıcındaki toksik görünüm nedeniyle bakteriyel sepsis ile karıştırılabilir ${ }^{5}$. Her ne kadar İAV enfeksiyonlarının birçoğu akut, kendini sınırlayan hafif solunum yolu bulguları ile prezente olsa da ciddi ve ölümcül sekonder bakteriyel pnömoni, hemorajik bronşit, bronşiolit, pulmoner ödem ve hemoraji ile seyreden alveolit tablolarına da yol açabilir' ${ }^{6}$. Dispne, takipne, göğüs ağrısı, hemoptizi, pürülan balgam, uzamış veya tekrarlayan ateş, bilinç değişikliği, dehidratasyon bulguları, iyileşme sonrası alt solunum yolu bulgularının tekrar ortaya çıkması hastalığın ciddiyeti ve komplikasyonları ile ilişkilidir ${ }^{7}$ Bilinç bulanıklığı, nöbet, ensefalopati, ensefalit ve kuadriparezi gibi nörolojik bulguların bazı ölümcül seyreden vakalarda gözlendiği bildirilmiştir ${ }^{8}$. Hastamızda enfeksiyon tablosu klasik grip semptomlarıyla başlayıp ilerleyen günlerde bulant1, kusma ve ishal eklenerek daha komplike hale gelmiştir. Bilinç bulanıklığı, bozulmuş böbrek fonksiyon testleri ve pnömoni bulguları ağır İAV enfeksiyonunun seyrinde görülmekle birlikte yüksek Pct ve CRP değerleri her ne kadar kültür ile doğrulanamasa da H1N1 pnömonisine sekonder bakteriyel enfeksiyon eklenmiş olabileceğini düşündürmektedir.

İAV pnömonisinde direkt radyografide diffüz interstisyel ve alveoler infiltrasyonlar izlenir. Lober veya multilober tutulum ise sekonder bakteriyel enfeksiyon durumunda gözlenir. BT'de özellikle alt lobları tutan buzlu cam görüntüsü, hava bronkogramları ve alveoler konsolidasyon izlenir ${ }^{7}$. Ölümcül H1N1 vakalarında en yaygın histopatolojik bulgular diffüz alveoler hasar, septal ödem, trakeit ve nekrotizan pnömonidir. Pulmoner vasküler konjesyon ve alveoler hemoraji diğer erken bulgular arasındadır ${ }^{7}$. Hastamızın sol akciğer solunum seslerinde azalmanın devam etmesi üzerine çekilen toraks BT'de nekrotizan pnömoni ile uyumlu görüntü ve bronşiektazi alanları izlendi.

İnfluenza A virus enfeksiyonu halen pediatrik ARDS'nin önde gelen sebeplerindendir. Kinikar ve ark. tarafından yapılan çalışmada, İAV enfeksiyonu nedeni ile hastaneye yatırılan çocukların \%18'inde ARDS geliştiği tespit edilmiştir ${ }^{3}$. Farias ve ark. tarafından yapılan çalışmada ise İAV enfeksiyonuna bağlı solunum yetmezliği gelişen hastaların \%80'inde ARDS tespit edilmiş olup bu hastaların \%45'i 28 gün içerisinde kaybedilmiştir ${ }^{9}$. Hastamızda H1N1 pnömonisi sonrası ARDS gelişmiş olup entübasyonun 20. gününde başarılı şekilde mekanik ventilatörden ayrılmış ancak ekstübasyondan 10 gün sonra masif pulmoner kanama nedeni ile kaybedilmiştir.

Gebelik döneminde immün sistemin baskılandığı bilinmekle birlikte postpartum dönemdeki immün süreç tam olarak bilinmemektedir. Gebelik döneminde viral enfeksiyonlara artmış duyarlılık, lenfosit alt gruplarındaki değişiklikler, özellikle gebeliğin son dönemlerinde büyük 
granüler lenfosit sayısı ve naturel killer aktivitesinin azalması ile açıklanmaya çalışılmaktadır ${ }^{10}$. Gebelik ile birlikte immün sistemde meydana gelen değişikliklerin tamamen normale dönmesi doğum sonrası 3 ila 4 ayı bulabilmektedir ${ }^{11}$. Öncesinde herhangi bir risk faktörü olmayan hastamızda gelişen ölümcül İAV enfeksiyonunda postpartum dönemde henüz tam olarak normale dönmeyen immün sistemin de etkisinin olabileceğini düşünmekteyiz.

Düşük sosyoekonomik seviyenin influenzaya bağlı mortaliteyi artırıcı bir faktör olduğu bildirilmektedir ${ }^{12}$. İngiltere'de yapılan bir çalışmada farklı sosyoekonomik seviyedeki hastaların mortalite oranları arasında 3 kata kadar fark bulunduğu saptanmıştır. Bunun sebepleri arasında kalabalık ortamlarda bozulmuş hijyen şartlarında yaşamak, beslenme eksikliğine bağlı faktörler, aşılanma gibi koruyucu sağlık hizmetlerinde farkındalığın yetersiz olması ve sağlık hizmetlerine ulaşmada zorluk gibi faktörlerin bulunduğu bildirilmektedir ${ }^{12}$. Daha yoksul, hijyen koşulları yetersiz ve kalabalık ortamlarda yaşayan bireylerde eğitim ve aşılama gibi koruyucu önlemlerle mortalitenin azaltılabileceği belirtilmektedir ${ }^{13}$. Hastamızda İAV enfeksiyonunun mortal seyretmesinin, soğuk kış şartlarına rağmen çadırda yaşaması ve sosyoekonomik düzeyinin oldukça düşük olmasının oldukça önemli faktörler olduğu düşünülmüştür.

\section{Sonuç}

Ciddi influenza enfeksiyonlarının kontrol altına alınması ve buna bağlı ölümlerin engellenebilmesi için hastanın sosyoekonomik düzeyi de dikkate alınarak çocukluk, gebelik, lohusalık ve diğer komorbid durumlar göz önünde bulundurularak erken dönemde koruyucu önlemler alınmalıdir. 
Journal of BSHR 2019;3(3):255-259

ELMAS, BIRCAN, ORHAN, ÖZDEMIR, Mortal H1N1 Pnömonisi

\section{Kaynaklar}

1. Mossad SB. The resurgence of swine-origin influenza A (H1N1). Cleve Clin I Med. 2009 Jun; 76(6):337-43.

2. Perez-Padilla $R$, de la Rosa-Zamboni D, Ponce de Leon $S$ et al. Pneumonia and respiratory failure from swine-origin influenza A (H1N1) in Mexico. N. Engl. J. Med. 2009; 361: 680-90.

3. Kinikar AA, Kulkarni RK, Valvi CT, et al. Predictors of mortality in hospitalized children with pandemic H1N1 influenza 2009 in Pune, India. Indian J Pediatr. 2012 Apr;79(4):45966.

4. Dawood FS, Iuliano AD, Reed C, et al. Estimated global mortality associated with the first 12 months of 2009 pandemic influenza A H1N1 virus circulation: a modelling study. Lancet Infect Dis. 2012 Sep;12(9):687-95.

5. DynaMed [Internet]. Ipswich (MA): EBSCO Information Services. 1995 - . Record No. T435305, Influenza in Children; [updated 2018 Nov 30, cited November 22, 2019]. Available from https://www.dynamed.com/topics/dmp AN T435305.

6. Taubenberger JK, Morens DM. The pathology of influenza virus infections. Annu Rev Pathol. 2008;3:499-522.

7. Bautista E, Chotpitayasunondh T, Gao Z, et al. Writing Committee of the WHO Consultation on Clinical Aspects of Pandemic (H1N1) 2009 Influenza. Clinical aspects of pandemic 2009 influenza A (H1N1) virus infection. N Engl J Med. 2010 May 6;362(18):1708 19.
8. Noriega LM, Verdugo RJ, Araos R, et al. Pandemic influenza A (H1N1) 2009 with neurological manifestations, a case series. Influenza Other Respir Viruses. 2010 May 1;4(3):117-

9. Farias JA, Fernández A, Monteverde E, et al. Critically ill infants and children with influenza A (H1N1) in pediatric intensive care units in Argentina. Intensive Care Med. 2010 Jun;36(6):1015-22.

10. Watanabe $M$, Iwatani $Y$, Kaneda Tet al. Changes in T, B, and NK lymphocyte subsets during and after normal pregnancy. Am J Reprod Immunol. 1997 May;37(5):368-77.

11. Groer ME, Jevitt C, Ji M. Immune changes and dysphoric moods across the postpartum. Am J Reprod Immunol. 2015 Mar; 73(3):193-8.

12. Rutter PD, Mytton OT, Mak M, et al. Socio-economic disparities in mortality due to pandemic influenza in England. Int J Public Health. 2012 Aug;57(4):745-50.

13. Chandrasekhar R, Sloan C, Mitchel E, et al. Social determinants of influenza hospitalization in the United States. Influenza Other Respir Viruses. 2017 Nov;11(6):479-488. 